\title{
THE IMPACT OF REPORT ANNOUNCEMENT IN WHEAT AND COTTON FUTURES RETURN VOLATILITIES
}

DOI: 10.17261/Pressacademia.2019.1140

PAP-IFC- V.10-2019(8)-p.36-41

\section{Orhan Ozaydin}

Istanbul Commerce University, PhD in Financial Economics, Istanbul, Turkey. orhanozaydin@gmail.com, ORCID: 0000-0003-2585-1437

To cite this document

Ozaydin, O., (2019). The impact of report announcement in wheat and cotton futures return volatilities. PressAcademia Procedia (PAP), V.10, p.36-42.

Permemant link to this document: http://doi.org/10.17261/Pressacademia.2019.1140

Copyright: Published by PressAcademia and limited licenced re-use rights only.

\section{ABSTRACT}

Purpose- Futures markets have been the focus of attention due to the increasing technology and globalization in recent years, both in terms of meeting the needs of hedgers and the benefit of speculators from these markets. The reports issued by the US Department of Agriculture (USDA) and the US-based Commodity Futures Trade Commission (CFTC) are closely monitored by the participants in the futures markets. These reports affect the prices, returns and volatilities of commodities as mentioned in the previous literature. It has been investigated whether the reports published for wheat and cotton commodities which are agricultural commodities futures have an effect on return volatilities in NYSE and CBOT futures exchanges on the day of publication, before and after.

Methodology- Yield variance was examined by using dummy variables over conditional heteroscedasticity models.

Findings- The effects of the report announcements yielded different results for two different commodities, with different effects on the variance of the commodity.

Conclusion- The effects of both USDA WASDE and CFTC COT reports on the return volatility have been seen statistically but limited. It will be beneficial to include these reports in the analysis of the effects of the futures markets on returns and price discovery studies.
\end{abstract}

Keywords: Futures, commodity markets, volatility, WASDE, COT.

JEL Codes:G13, Q02, Q11

\section{TARIM VADELI IŞLEM PIYASASINDA RAPOR GÜNÜNÜN GETIRI OYNAKLIĞINA ETKISI: BUĞDAY VE PAMUK ÜZERINE BIR UYGULAMA}

\section{ÖZET}

Amaç- Vadeli piyasalar, hem fonksiyonel açıdan korumacıların ihtiyaçlarını karşılaması hem de spekülatörlerin bu piyasalardan fayda sağlaması sebebiyle son yıllarda artan teknoloji ve globalleşme sayesinde ilgi odağı olmuştur. Amerika Tarım Bakanlığı (USDA) ve ABD merkezli Emtia Vadeli İşlem Ticari Komisyonu (CFTC) yayınladıkları raporlar vadeli işlem piyasasındaki katılımcıların yakından takip ettiği raporlardır. Bu raporlar, literatürde bahsi geçtiği üzere emtia fiyatlarını, getirilerini ve oynaklıkları etkilemektedir. Vadeli tarım emtialarından -Türkiye'yi yakından ilgilendiren- buğday ve pamuk emtiaları için yayınlanan raporların NYSE ve CBOT vadeli işlem borsasındaki getiri oynaklıklarına rapor yayınlanma günü, önceki ve sonraki günlerde etkisinin olup olmadığı araştırılmıştır.

Yöntem- Koşullu değişen varyans modelleri üzerinden kukla değişkenler yardımıyla getiri varyansı incelenmiştir.

Bulgular- Rapor yayınlanma günü etkileri iki farklı emtia için farklı sonuçlar vermiş, emtia özelinde varyans üzerine farklı etkiler görülmüştür.

Sonuç- Yapılan araştırmalar sonucunda hem USDA WASDE raporu hem de CFTC COT raporunun yayınlandığı günlerin getiri oynaklığına etkileri sınırlı olsa da görülmüştür. Bu raporların vadeli işlem piyasalarında getiri üzerindeki etkileri ve fiyat keşfi çalışmalarında analizlere dahil edilmesi faydalı olacaktır.

Anahtar Kelimeler: Vadeli işlemler, emtia piyasaları, oynaklık, WASDE, COT.

JEL Kodları:G13, Q02, Q11

\section{GíRiş}

Vadeli işlem piyasalarının risk transferi fonksiyonunun işlevi, korumacıların karşısında riski transfer edebilecekleri piyasa katılımcıları bulmaları ile sağlanır. Vadeli piyasalar, hem fonksiyonel açıdan korumacıların ihtiyaçlarını karşılaması hem de spekülatörlerin bu piyasalardan fayda sağlaması sebebiyle son yıllarda artan teknoloji ve globalleşme sayesinde ilgi odağı olmuştur. 2008 krizi ile birlikte 
spekülatörlerin vadeli işlem piyasalarındaki varlıkları sorgulanır hale gelmiştir. ABD Emtia Vadeli İşlem Ticaret Komisyonu'na (CFTC: Commodity Futures Trading Commission) kayıtlı vadeli işlem aracı kuruluşlarının (FCM: Futures Commission Merchant) müşteri hesaplarındaki yirmi yıllık gelişmeye bakıldığında ilginin büyüklüğü anlaşılmaktadır; 2002 yılında 64.3 milyar USD olan vadeli işlem fonları devamlı artışını sürdürmüş ve 2002 yılına göre 2018 yılında \%354 artışla 291.8 milyar dolar gerçekleşmiştir(CFTC, 2018)

Vadeli işlem piyasalarındaki katılımcılar, ihtiyaçları ya da piyasa beklentileri üzerine kontrat satın alır satar. Bir piyasada fiyatlar temel olarak arz ve talep kanunları çerçevesinde oluşur ve vadeli işlem piyasaları için de bu kavram geçerlidir (Hull, 2012). Katılımcıları etkileyen ve dolayısıyla fiyatlara etki eden temel unsurlardan biri saygın kurumların yayınladığı durum raporları ya da beklenti raporlarıdır. Vadeli emtia işlem piyasalarını yakından ilgilendiren USDA ve CFTC iki önemli raporu düzenli yayınlamaktadır. Sırasıyla USDA'nın aylık yayınlanan sezonsal üretim, tüketim ve stok miktarlarını tahmin eden WASDE (Dünya Tarım Arz Talep Tahminleri) raporu ve CFTC'nin yayınlanankatılımcıların pozisyon bilgilerini içeren COT (Tüccarların taahhütleri) Raporudur. Uluslararası literatürde bu raporlarla ilgili birçok çalışma mevcuttur. Bu raporların emtia ve dönem özelinde getiri ve oynaklığa etkileri bulgularda yer almıştır.

Ying ve diğerleri (2019), Ocak 1995 ile Aralık 2015 tarihleri arası en yakın vadeli mısır ve soya CBOT kontratı üzerine WASDE raporu yayınlanma günü etkisini modele kukla değişken ekleyerek araştırmıştır. Wasde raporunda mısır ve soya için bazı dönemlerde oynaklığı \%10 anlamlık seviyesinde etkili olduğu çıkmıştır. Raporun trend etkisinin yıllar geçtikçe arttığını söylemiştir. Bunek ve Janzen (2015), 2008 başından 2012 sonuna kadar 75 adet yayınlanan USDA WASDE raporunun KBOT'daki buğday vadeli işlem piyasasındaki volatilitesini modellemiş ve raporun yayınlanma tarihinin bir etkisi olup olmadığını araştırmıştır. Regresyon modeline kontrol değişkenleri koyarak, rapor yayınlanma günündeki kukla değişken katsayıların büyüklüğü, pozitif olması ve anlamlı olması oynaklığın rapor günlerinde yüksek olduğu göstermektedir. Isengildina-Massa ve diğerleri (2008), 1985 ile 2006 yılları arası CBOT (Chicago Vadeli İşlem Emtia Borsası) mısır ve soya emtiaları getiri varyansları ile WASDE raporunun yayınlanma günü etkileşimini araştırmıştır. Mısır için rapor günlerinde tüm aylara göre getiri varyansı 3,70 kat fazla ve soya için getiri varyansı tüm aylara göre 3.84 kat daha fazladır. Sunulan test istatistiklerinin mısır ve soya fasulyesi için rapor günleri oynaklıktaki artışın \%1 düzeyinde istatistiki anlamlı olduğunu göstermektedir. Karali(2012), 1993 ile 2008 arası multivarite GARCH model kullanarak mısır, soya, soya yağı vadeli kontrat getiri varyanslarının USDA raporlarının- Feed Outlook ve Grain Stocks - yayınlandığı günlerde nasıl etkilendiğini araştırmıştır. Rapor yayınlanma günlerini kukla değişken olarak kullanılan çalışmada, mısır ve soya getirisinin koşullu varyansının USDA raporlarının yayınlandığı gün arttığını söylemektedir. USDA raporlarının yayınlanması ile piyasaya yeni bir bilgi sağlandığı anlaşılmaktadır. Ho \& Lauwer(2018), Ağustos 2006 ile Eylül 2018 arası CFTC COT raporlarından edindiği ticari aktivite bilgileri, pozisyon bilgileri ile bu raporlarda işlem gören emtiaların hisse senedi piyasasında işlem göre şirketler ile faaliyetlerine göre eşleştirip hisse getirisinin önceden tahmin edilip edilemeyeceğini araştırmışlardır. Panel veri ile yaptıkları çalışmalarından çıkan sonucun CFTC'nin COT raporundaki salıdan çarşambaya olan işlemlere göre getirinin önceden tahmin edilebilirliğinin güçlü, pazartesinden cumaya olan işlemlerin ise getirinin tahmin edilebilirliği zayıf sonucu çıkmıştır. Takvim etkisi açısından bu çalışma ile ilişkilendirildiğinde, СOT raporlarının cuma günü kapanıştan sonra yayınlandığı ve rapor günü etkisinin pazartesiden cumaya olacağı düşünüldüğünde, hisse senetlerinin tahmin edilebilirliği konusunda diğer araştırma unsuru olan salıdan çarşambaya göre zayıf bir aralık süresi olduğu sonucu çıkmaktadır. Yani rapor gününün etkisi yoktur denilebilir. Bu çalışmada haftanın her günü için ayrı olarak getiri oynaklıkları incelenmiş ve yorumlanmıştır. İstatistiki olarak pamuk için rapor etkisi görülmüş, buğday için bu etki bulgularda çıkmamıştır.

Vadeli işlem borsalarında emtialar alt gruplara ayrılmıştır. Her ne kadar tarım ayrı bir grup olarak nitelendirilse de, tarım altında hububat (grain) ve yumuşak (soft) alt emtia grupları oluşturulmuştur. Hububat gurubunun altında buğday, yulaf, soya, mısır gibi tarım ürünleri işlem görürken, soft grubunun altında pamuk, kahve, kakao gibi tarım emtiaları işlem görmektedir (CME, 2019). Tablo 1'de Dünya ve Türkiye kıyaslamalı buğday ve pamuk üretim verileri gösterilmiştir. TMO raporuna göre 2017/18 sezonunda buğday hububatında Türkiye, Dünya'da \%2.8'lik üretim payına sahiptir ve yıllık üretimi 21.5 milyon tondur. Aynı rapora göre pamuk üretiminde Türkiye, Dünya'da \%3.2'lük üretim payına sahiptir ve yıllık üretimi 870 bin tondur. Bu çalışmada NYSE ve CBOT vadeli işlem borsalarında işlem gören ve Türkiye'yi ilgilendiren bir hububat emtiası buğday ve bir soft emtia olan pamuk vadeli işlem kontratlarının getirileri üzerinde WASDE ve COT raporlarının yayınlanma günü etkisinin cevabı araştırılmıştır.

Tablo 1:2017/2018 Sezonu Üretim Miktarları Milyon Ton

\begin{tabular}{|c|c|c|}
\hline & Buğday & Pamuk \\
\hline Dünya & 763.0 & 26.9 \\
\hline Türkiye & 21.50 & 0.87 \\
\hline$\%$ & $2.8 \%$ & $3.2 \%$ \\
\hline
\end{tabular}

Kaynak: Hububat Sektör Raporu, TMO (2019).

Yöntem olarak, farklı koşullu varyans modelleri veriler üzerinde denenmiştir Koşulları sağlayan en düşük Akaikeli modeller seçilmiştir. Buğday ve pamuk getiri varyans modeline kukla değişkenleri eklenerek kurulan modelde, varyansın istatistiki açıdan rapor gününden etkilenip etkilenmediği bulgularına bakılmıştır. Her iki emtia için farklı etki sonuçları elde edilmiştir. Ekonometrik bulgular, emtialara göre değişkenlik arz etmiştir. Yapılan araştırmalar sonucunda hem USDA WASDE raporu hem de CFTC COT raporunun yayınlandığı günlerin getiri oynaklığına etkileri sınırlı olsa da görülmüştür. Bu raporların vadeli işlem piyasalarında getiri üzerindeki etkileri ve fiyat keşfi çalışmalarında analizlere dahil edilmesi faydalı olacaktır.

\section{WASDE VE COT RAPORLARI}

Amerika Tarım Bakanlığı dünya genelinde tarım emtialarının arzının ve talebinin takibini yapabilmek adına ve kendi politikalarına yön verme amacıyla çeşitli kaynaklardan düzenli bilgi toplayarak hazırladığı belli başlı raporları halka açık olarak da paylaşmaktadır. Bu raporlar, belirlenmiş tarım emtialarının dünya genelini kapsayacak şekilde miktarsal olarak raporlandığı ve gelecek sezon tahmin verilerinin bulunduğu rakamları içermektedir. Bilginin doğru ve aynı anda piyasaya yayılması adına USDA yayınladığı raporlara azami önem vermektedir. Bu raporlar serbest piyasada ve vadeli işlem piyasasında işlem yapan birçok yatırımcı ve üretici tarafından yakından 
izlenmektedir. WASDE raporları her emtia için arz (başlangıç stokları, ihracat ve üretim) ve talep (iç tüketim ithalat ve dönem sonu stoklar) bileşenlerinden oluşan eşit bir bilanço tahmini sunmaktadır. Aylık yayınlanan bu rapordaki veriler, önümüzdeki sezonun yıllık beklenen verilerini içerir. Emtia özelinde dünyada önde gelen büyük üretici ve tüketici ülkeler raporda ayrı olarak gösterilmektedir. Genel olarak USDA raporları piyasaya bilgi sağlayıcı ve piyasayı etkileyici raporlardır. Bunun ana sebepleri, öncelikle USDA raporlarının kalitesi ve doğruluğudur, ikinci olarak özel sektöre kıyasla devlet kaynakı bir raporun katılımcılar tarafından daha güvenilir bulunmasıdır ve son olarak gelişen internet teknolojisi sayesinde bu raporlar çok daha büyük bir kitlelere eş zamanlı olarak ulaşabilmektedir(Ying, Chen, \& Dorfmann, 2019). WASDE raporunda bilgi güvenliği çok hassas olarak kontrol altında tutulmaktadır, raporu hazırlayanların tüm dünya ile iletişimi raporun yayınlanacağı ABD saatiyle sabahtan öğleden sonra 12:00'ye kadar kesilir (NASS, 2019).

Temel tanım olarak COT raporu CFTC tarafından düzenli yayınlanan, vadeli emtia piyasalarında işlem yapan ve elinde belli büyüklükte kontrat olan piyasa oyuncularının belirli bir dönemdeki vadeli işlem pozisyonları hakkında bilgi içeren rapordur. CFTC'nin haftalık yayınladığı COT raporu, ABD vadeli işlem piyasalarındaki ticari olmayan yatırımcıların ve ticari faaliyet ilişkisi olan korumacıların net pozisyonlarındaki eğilimleri göstermektedir. Tüm veriler, Chicago ve New York vadeli işlemler borsalarındaki katılımcıların pozisyonlarını yansıtmaktadır. COT raporu, piyasa hissiyatını anlamayı ve ne kadar spekülatif yatırımcının hangi pozisyonda kısa veya uzun işlem yaptığı konusunda fikir vermeyi amaçlamaktadır. CFTC'ye göre raporlanan pozisyonlar, vadeli işlem piyasalardaki büyüklüğü \%70-\%90 oranında açıklamaktadır. Katılımcılardan gelen pozisyon verileri haftanın Salı günü itibariyle açık pozisyonlarını içerir. Rapor, her Cuma ABD saati ile15:30`da yayınlanarak yatırımcıların Salı gününden önceki eğilimleri konusunda piyasalara fikir verir. Bir piyasa katılımcısının ticari korumacı olarak atfedilmesi, piyasada yapmış olduğu işlemin koruma amaçlı olmasına bağlıdır. CFTC düzenlemelerinin uyumuna göre bunlar belirlenir. Tersi ise ticari olmayan, spekülatif olarak adlandırılmıştır. CFTC, emtianın fiziksel faaliyet ticaretinde olmayan, koruma yapmayan ama başarılı fiyat beklentileri amaçlayarak piyasadan kar hedefleyen hedge fonları, spekülatif piyasa oyuncularını ticari olmayan oyuncular olarak tanımlamıştır. Ticari oyuncular ise üretimin içinde olan, süreçlerde ya da emtianın ticaretinde faaliyet gösteren tüccarlardır (Kolodziej, 2013). Burada vadeli işlemler ve opsiyon pozisyonları kombine, birlikte yayınlanmaktadır. Spekülatif amaçlı yatırım yapan ve genelde nette uzun pozisyonda olan spekülatörler, koruma amacında olan üretici ve tüccarlar ve pasif ticaret yapan endeks yatırımcılar -emeklilik fon yatırımları vb.- uzun ve kısa pozisyonlarının miktarları bu raporda yayınlanır. Büyük grupların yatırımlarını hangi yöne yaptıklarını görmek açısından CFTC COT raporu oldukça önemlidir.

\section{VERI VE YÖNTEM}

2008 krizinden sonraki 2009 ile 2018 yılları arası 10 yıllık veri seti bu çalışmada kullanılmıştır. Rapor günü etkisi incelenmesi amacıyla vadeli pamuk emtiası fiyat verisi NYSE:ICE vadeli işlem borsasından günlük kapanış verisi olarak temin edilmiştir. NYSE:ICE işlem saatleri ABD saati ile hafta içi 21:00 den 14:20 ye kadardır(ICE, 2019).Buğday günlük kapanış fiyat verisi CBOT’tan temin edilmiştir ve CBOT işlem saatleri ABD saati ile hafta içi 19:00-7:45 ve 08:30-13:20'dir (CME Group, 2019). Genel literatürde kullanıldığı gibi en yakın vadeli kontrat verileri kullanılmıştır. Buğday için kontrat ayları mart, mayıs, temmuz, eylül ve aralıktır. Pamuk için ise mart, mayıs, temmuz, ekim ve aralıktır. Getiri verisi için günlük fiyat değişiminin logaritmik farkı alınmıştır ve her iki emtia için 2609 günlük getiri verisi oluşturulmuştur.

$$
R(t)=L N(P(t) / P(t-1))
$$

Tablo 2: СВОТ Buğday ve Pamuk En Yakın Vadeli Kontrat Getiri Verisi Temel İstatistik Sonuçları

\begin{tabular}{|l|l|l|l|l|l|}
\hline $\begin{array}{l}\text { Getiri } \\
\text { İstatistik }\end{array}$ & Buğday (GB) & Pamuk (GP) & $\begin{array}{l}\text { Getiri } \\
\text { İstatistik }\end{array}$ & Buğday (GB) & Pamuk (GP) \\
\hline Ortalama & -0.000079 & 0.000144 & Eğiklik & 0.193468 & -0.611571 \\
\hline Medyan & 0.000000 & 0.000000 & Basılık & 4.925834 & 8.181062 \\
\hline Maks & 0.087688 & 0.069641 & Jarque-Bera & 418.4924 & 3073.653 \\
\hline Min & -0.099728 & -0.155547 & JB olasılık & 0.000000 & 0.000000 \\
\hline Std.Sapma & 0.019558 & 0.017522 & \multicolumn{3}{|l}{} \\
\cline { 1 - 3 }
\end{tabular}

Buğday getiri verisi “GB" ve pamuk getiri verisi “GP” olarak kodlanmıştır. Verilerin ilk istatistiki sonuçları tablo 2'de görülmektedir. Her iki veri için basıklık 3'ten büyük çıkmıştır. Jarque-Bera normallik test olasılık değeri \%0 çıkmış ve verilerin normal dağılıma sahip olmadığı görülmüştür. Genellikle bu bulgular koşullu değişen varyans içeren finansal verilerde görülmektedir, çalışmanın ilerleyen bölümlerinde verilerde arch etkisi olup olmadığı kontrol edilmiştir, arch etkileri görülmüştür.

WASDE raporları USDA tarafından her ayın 9 ile 12. günleri arasında ABD saati ile öğlen 12:00'de yayınlanmaktadır. Rapor, konu geçen emtianın, dünya ve ülkeler bazında önündeki sezonda olabilecek üretim, tüketim ve stok tahminlerini içermektedir. Çalışma kapsamında kullanılan veriler 120 aylık tarih verisinden oluşmaktadır yani WASDE raporlarında 120 adet rapor yayınlanma kukla verisi vardır. Bu raporun yayınlanma günü ve önceki 5 günü sonraki 5 gününe kukla değişken atanarak varyans modeline bağımsız dışsal değişken olarak eklenmiştir. COT raporları haftanın Cuma günleri NYSE ve CBOT borsaları işleme kapandıktan sonra ABD saati ile 15:30 da yayınlanmaktadır. COT raporunun etkisi Cuma sonrası ilk işlem günü olan pazartesi günü olacağı düşünülmektedir. COT raporu etkisinin ölçmek üzere haftanın 5 günü için 5 farkı kukla değişken tanımlanmıştır. Haftalık bir kukla değişken için 2609 getiri verisi üzerine 522 COT raporu yayınlanma tarihi verisi vardır.

WASDE raporları USDA tarafından her ayın 9 ile 12. günleri arasında ABD saati ile öğlen 12:00'de yayınlanmaktadır. Rapor, konu geçen emtianın, dünya ve ülkeler bazında önündeki sezonda olabilecek üretim, tüketim ve stok tahminlerini içermektedir. Çalışma kapsamında kullanılan veriler 120 aylık tarih verisinden oluşmaktadır yani WASDE raporlarında 120 adet rapor yayınlanma kukla verisi vardır. Bu raporun yayınlanma günü ve önceki 5 günü sonraki 5 gününe kukla değişken atanarak varyans modeline bağımsız dışsal değişken olarak eklenmiştir. COT raporları haftanın Cuma günleri NYSE ve CBOT borsaları işleme kapandıktan sonra ABD saati ile 15:30 da yayınlanmaktadır. COT raporunun etkisi Cuma sonrası ilk işlem günü olan pazartesi günü olacağı düşünülmektedir. COT raporu etkisinin ölçmek üzere haftanın 5 
günü için 5 farkı kukla değişken tanımlanmıştır. Haftalık bir kukla değişken için 2609 getiri verisi üzerine 522 COT raporu yayınlanma tarihi verisi vardır.

Oynaklığı açıklamada farklı yazarlar farklı tanımlamalarda bulunmuşlardır. Oynaklık (değişkenlik ya da volatilite), bir enstrümanın fiyatında meydana gelen değişimin istatistiksel ölçüsüdür (Butler, 1999, s. 190). Finansal piyasalara bakıldığında, uygulamada oynaklıktan söz edilirken genellikle varyansın karekökü olan standart sapmadan bahsedilir (Sinclair, 2008, s. 16). Bu çalışmada koşullu değişen varyans modellemeleri sonucunda oluşan varyans denklemi üzerinden kukla değişkenlere göre varyans değişimleri incelenmiştir. ARCH ve GARCH modelleri, değişken oynaklığa sahip finansal zaman serileri için varyansın sabit kalmadığını öngören ve doğrusal olmayan ekonometrik modellerdir. ARCH modelleri finansal piyasa analizlerinde yaygınca kullanılan bir yöntemdir (Gökbulut \& Pekkaya, 2014). Getiri verilerinde ARCH LM testleri sonucunda ARCH etkisi görülmüştür. Genel literatürde ARCH ve GARCH modelleri kullanılması sebebiyle modellere farklı arch ve garch gecikmeleri uygulanmış, bunun sonucunda buğday için $\mathrm{GARCH}(1,1)$ ve pamuk için $\mathrm{GARCH}(1,2)$ modellerinin koşulları sağlayan ve Akaikesi en düşük uygun modeller olarak belirlenmiştir.

Bollerslev (1986), ARCH modellerini genelleştiren kullanışlı bir modeli GARCH olarak tanıtmıştır. Daha fazla geçmiş bilgiye ve esnek gecikme yapısına sahip olan bir model yapısı geliştirmiştir. GARCH modeline göre koşullu varyans, sadece geçmiş dönem hata karelerinin gecikmeli değerlerine değil, bağımlı değişkenin geçmiş dönem koşullu varyansının geçmiş dönem değerlerine de bağlıdır. Bu model, oynaklığı, piyasaya beklenmedik bilgi şoklarının bir fonksiyonu olarak parametrize etmektedir. Genel bir GARCH(p,q) süreci, hata karelerinin gecikme uzunluğu q (arch gecikmesi) ve otoregresif kısmının gecikme uzunluğu da p (garch gecikmesi) ile ifade edildiğinde,

$\omega \geq 0 ; \quad \alpha_{\mathrm{i}} \geq 0 ; \quad B_{\mathrm{j}} \geq 0 ; \quad \sum_{j=1}^{p} \beta_{j}+\sum_{i=1}^{q} \alpha_{i}<1 ;$ koşulları sağlanma şartıyla;

$\mathrm{h}_{t}=\sigma_{t}^{2}=\omega+\sum_{j=1}^{p} h_{t-j} \beta_{j}+\sum_{i=1}^{q} u_{t-i}^{2} \alpha_{i}$

denklemi şeklinde yazılabilir. Modelin parametrelerinin kestirimlerinde "En Çok Olabilirlik" (Max. Likelihood) yöntemi kullanılmaktadır. Koşullu varyans denklemi oluşturulduktan sonra modelin geçerliliği açısından tahmin edilen ARCH ve GARCH modelinin parametrelerinde iki koşul aranmaktadır. İlki negatif olmama koşuludur; varyansın pozitif olması için koşullu varyans denkleminin sabit katsayının sıfırdan büyük $(\omega>0)$ ve diğer değişkenlerin katsayılarının sıfıra büyük eşit olmasıdır ( $\left.\alpha_{i} \geq 0 ; \beta_{j} \geq 0 ; i=1,2, . ., q\right)$. İkinci koşul ise, otoregresif modellerle ilgili durağanlık koşuludur. Koşullu varyans denkleminin sabit dışındaki diğer tüm parametrelerin toplamının birden küçük çıkması gerekmektedir, böylece durağanlık şartı sağlanmış olacaktır(Özden, 2008).

\section{BULGULAR}

Öncelikle getiri verilerinin durağanlığı test edilmiştir (Tablo 3). Verilerde birim kök olmadığı anlaşılmıştır. Bir zaman serisi değişkeninin gecikmeli değerleri arasındaki birlikte değişimin bir ölçüsü otokorelasyon ve otokovaryans olarak adlandırılır(Sevütekin \& Nargeleçekenler, 2010, s. 251). EKK yöntemi ile sabit kurulan modellerde serisel korelasyon LM test ile kalıntılarda otokorelasyon sorununun varlığı araştırılmıştır (tablo 4). 5 gecikmede bakılan buğday verisinde, T'nin gözlem sayısı olduğu yerde, T*R-kare7.5460, Ki-Kare olasılık değerli \%18 çıkmıştır. Buğday için modelin kalıntılarında ya da seride otokorelasyon sorunu yoktur. Yine 5 gecikmede bakılan pamuk verisinde, T’nin gözlem sayısı olduğu yerde, T*R-kare46.4785, Ki-Kare olasılık değerli \%0 çıkmıştır. Pamuk için modelin kalıntılarında ya da seride otokorelasyon sorunu ortaya çıkmaktadır. Ayrıca GP getiri serisinin korelogram grafiği incelendiğinde birinci dereceden gecikme olduğu da görülmüştür. Pamuk verisinde günlük getirilerde görülen oto korelasyon sebebiyle getirilere bir gecikme eklenmiş ve tekrar yapılan serisel korelasyon LM testi ile bu sorun ortadan kalktığı görülmüştür, T’nin gözlem sayısı olduğu yerde, T*R-kare 8.4539, Ki-Kare olasılık değerli \%13 çıkmıştır. Kurulan EKK ve GARCH modelinin ortalama denklemleri denklem 3 ve 5 'de gösterilmektedir.

Tablo 3: Birim Kök İstatistiki Sonuçları (Sabit Terimli)

\begin{tabular}{|l|l|l|l|}
\hline \multirow{2}{*}{ Birim Kök } & ADF & PP & KPSS \\
\cline { 2 - 4 } & t-istk. & t-istk. & t-istk. \\
\hline GB & -51.6096 & -51.6318 & 0.034084 \\
\hline GP & -45.1611 & -45.1132 & 0.178768 \\
\hline
\end{tabular}

* Test sonuçlarına göre her iki seri \%1 istatistiki anlamlılık ile birim kök içermemektedir.

Tablo 4: Serisel Korelasyon-LM ve Arch-LM İstatistiki Sonuçları

\begin{tabular}{|c|c|c|c|c|c|c|c|c|}
\hline & \multicolumn{4}{|l|}{ Seri-LM } & \multicolumn{4}{|l|}{ Arch-LM } \\
\hline & \multicolumn{2}{|l|}{ Önce } & \multicolumn{2}{|l|}{ Sonra } & \multicolumn{2}{|l|}{ Önce } & \multicolumn{2}{|l|}{ Sonra } \\
\hline & T*R-kare & Ki-Kare(5) & T*R-kare & Ki-Kare(5) & $\mathrm{T}^{*} \mathrm{R}$-kare & Ki-Kare(5) & T*R-kare & Ki-Kare(5) \\
\hline GB & 7.546 & 0.183 & - & - & 46.625 & 0.000 & 1.262 & 0.939 \\
\hline GP & 46.478 & 0.000 & 8.454 & 0.133 & 334.264 & 0.000 & 6.791 & 0.237 \\
\hline
\end{tabular}

Denklem 3 ve 5 üzerinde buğday ve pamuk getiri modelleri için ARCH-LM testi yapılmış (tablo 4) ve modellerde ARCH etkisi olması sebebiyle koşullu değişen varyans modelleri arasından uygun olan sırasıyla $\operatorname{GARCH}(1,1)$ ve $\mathrm{GARCH}(1,2)$ modelleri kurulmuştur. Her iki veri için GARCH modellerinin varyans denklemine rapor gününün etkisinin varlığını ölçmek üzere denklem 4 ve 6'daki gibi dışsal kukla değişkenleri eklenmiştir(Atakan, 2008).

$$
\begin{aligned}
& R_{\text {bugday }}(t)=c+u t \\
& h t=a+b^{*} u(t-1)^{\wedge} 2+c^{*} h(t-1)+d^{*} D(t)
\end{aligned}
$$




$$
\begin{aligned}
& R_{\text {pamuk }}(t)=b \cdot R_{\text {pamuk }}(t-1)+c+u t \\
& h t=a+b^{*} u(t-1)^{\wedge} 2+c^{*} h(t-1)+d^{*} h(t-2)+e^{*} D(t)
\end{aligned}
$$

WASDE raporunun vadeli buğday emtiasının getiri varyans denklemi için kukla değişkeninin katsayısına bakıldığında (Tablo 5), raporun yayınlandığı günün getiri varyansını arttırıcı etkisi olsa bile istatistiki olarak bu sonuç anlamlı çıkmamaktadır. Raporun yayınlandığı gün için Diğer günlerde varyansı düşürücü etkisi olduğu görülmektedir. Ancak rapor yayınlandığı 3. günde ve sonrasında oynaklığa düşürücü etkisi olmuş ve istatistiki anlamlı sonuçlar çıkmıştır. Rapor verilerinin piyasada algılanıp ancak piyasa katılımcıları tarafından fiyatlanması bu sonucu sebep olabilmektedir.

WASDE raporunun vadeli pamuk emtiasının getiri varyans denklemi için kukla değişkeninin katsayısına bakıldığında ise (Tablo 5), rapor yayınlandığı gün \%10 anlamlılık seviyesinde oynaklığa pozitif yansıma olduğu görülmüştür. Raporun yayınlanmasının pamuk vadeli getiri oynaklığını arttırdığı söylenebilir. Rapordan bir gün önce kukla değişken katsayısı anlamsızdır, pamuk vadeli emtiası için WASDE raporunun yayınlanma tarihinden önceki gün raporun oynaklıkta istatistiki olarak etkisi olmadığı söylenebilir. Daha önceki günlerde ise oynaklık pozitif olarak etkilenmekte ve sonuçlar istatistiki olarak anlamlıdır. Raporun yayınlanma beklentisi ile yapılan spekülasyonların bir sonucu olarak bu etki söylenebilir. Rapordan bir gün sonra ise kukla değişken katsayıları istatistiki \%1 anlamlılık seviyesinde negatif etkili sonuç vermiştir. Rapor sonrası günün oynaklığa negatif bir etkisi olduğu ve istatistiki olarak anlamlı olduğu görülmüştür. Bunun sebebi rapordan bir gün sonra fiyatların rapordaki bilgiler ışığında piyasa tarafından yerine oturması olarak anlamlandırılabilir.

Tablo 5: WASDE Rapor Günlerinin Varyans Üzerine İstatistiki Model Sonuçları

\begin{tabular}{|l|c|c|c|c|c|}
\cline { 3 - 6 } \multicolumn{2}{c}{} & \multicolumn{2}{c|}{ Buğday } & \multicolumn{2}{c|}{ Pamuk } \\
\hline WASDE Rapor Günü & Değişken & Kukla Katsayı & Kukla olasılık & Kukla Katsayı & Kukla olasılık \\
\hline 5 Gün önce & DMY_E5 & -0.000028 & 0.157900 & 0.000046 & 0.063300 \\
\hline 4 Gün önce & DMY_E4 & -0.000041 & 0.039900 & 0.000088 & 0.000000 \\
\hline 3 Gün önce & DMY_E3 & -0.000049 & 0.020000 & 0.000077 & 0.001100 \\
\hline 2 Gün Önce & DMY_E2 & -0.000008 & 0.707400 & 0.000104 & 0.000000 \\
\hline 1 Gün Önce & DMY_E1 & 0.000002 & 0.912900 & -0.000019 & 0.192200 \\
\hline Rapor günü & DMY_0 & 0.000025 & 0.254100 & 0.000028 & 0.081700 \\
\hline 1 Gün sonra & DMY_A1 & -0.000017 & 0.412500 & -0.000084 & 0.000000 \\
\hline 2 Gün sonra & DMY_A2 & -0.000014 & 0.491300 & -0.000041 & 0.018500 \\
\hline 3 Gün sonra & DMY_A3 & -0.000041 & 0.029300 & -0.000076 & 0.000000 \\
\hline 4 Gün sonra & DMY_A4 & -0.000072 & 0.000200 & 0.000004 & 0.821300 \\
\hline 5 Gün sonra & DMY_A5 & -0.000107 & 0.000000 & -0.000029 & 0.124400 \\
\hline
\end{tabular}

ABD saati ile Cuma günleri 15:30 da yayınlanan CFTC'nin COT raporu NYSE:ICE'ın 14:20'deki ve CBOT'un 13:20'deki kapanışından sonra yayınlanmaktadır. Rapor gününün vadeli buğday ve pamuk emtiası varyansı üzerine etkisi pazartesi günü ve sonrası olacağı düşünülmektedir. Buğday için salı gününde istatistiki olarak anlamlı ve varyansı düşürücü etki görülmüştür (Tablo 5), düğer günler anlamlı sonuçlar çıkmamıştır. Salı gününde anlamlı ve negatif etkili çıkmasının bir sebebi hafta sonu ve pazartesi günü işlenen verilerin salı günü fiyatlara yansıması ve piyasanın daha kararlı bir fiyat belirlemesi olabilir. Pamuk emtiası için ise pazartesi günü varyansı diğer günlere göre yüksek etkilenmiş ve istatistiki olarak \%1 seviyesinde anlamlı sonuçlar vermiştir (Tablo 6). COT raporlarının Pazartesi günü pamuk oynaklığına pozitif etkisinin varlığı söylenebilmektedir. Her ne kadar Çarşamba ve Cuma günlerinde de kukla değişkenler anlamlı sonuç verseler de oynaklık bu günlerde düşmüştür. Bu çalışmanın bulgularına göre, pamuk oynaklığında pazartesi günü görülen pozitif etkinin COT raporları sebebiyle olabileceği gibi, bu pozitif etki hafta sonu biriken birçok bilginin pazartesi günü fiyatlara yansıması(Ying, Chen, \& Dorfmann, 2019)şekliyle de olabileceği ihtimaller arasındadır.

Tablo 6:COT Rapor Günlerinin Pamuk Getirisi Varyans Üzerine İstatistiki Model Sonuçları

\begin{tabular}{|l|l|c|c|c|c|}
\cline { 3 - 6 } \multicolumn{2}{c|}{} & \multicolumn{2}{c|}{ Buğday } & \multicolumn{2}{c|}{ Pamuk } \\
\hline COT Rapor günü & Değişken & Kukla Katsayı & Kukla olasılık & Kukla Katsayı & Kukla olasılık \\
\hline Pazartesi (COT etki) & DMY_2PZT & -0.000001 & 0.957600 & 0.000080 & 0.00000 \\
\hline Salı & DMY_3SAL & -0.000049 & 0.030500 & 0.000008 & 0.64140 \\
\hline Çarşamba & DMY_4CAR & 0.000027 & 0.261000 & -0.000046 & 0.00000 \\
\hline Perşembe & DMY_5PER & 0.000004 & 0.842000 & 0.000039 & 0.01220 \\
\hline Cuma & DMY_6CUM & 0.000019 & 0.310600 & -0.000058 & 0.00000 \\
\hline
\end{tabular}

\section{SONUÇ}

Vadeli işlem borsalarına ilgi piyasanın katılımcılara sağladı̆̆ fonksiyon ve faydalardan ötürü son yıllarda teknoloji ve küreselleşmenin etkisi ile artmıştır. Birçok katılımcı bu piyasalarda işlem yapmaktadır. Beklentilerini ve fiyatlamalarını farklı dinamiklere göre karar veren piyasa, daha çok saygın kurumların yayınladığı düzenli raporları dikkate almaktadır. Bunlardan USDA'nın yayınladığı ve CFTC'nin yayınladığı raporlar ön planda tutulmaktadır. Bu çalışmada WASDE ve COT raporlarının Türkiye'yi ilgilendiren iki önemli tarım emtiasının vadeli işlem getiri oynaklığı üzerinde yayınlanma günü etkisinin olup olmadığı araştırılmıştır.

Bir hububat emtiası olan buğday ve bir soft emtia olan pamuk vadeli emtia getirilerinin oynaklıkları koşullu değişen varyans modelleri yardımı ile incelenmiştir. 2009 ile 2018 yılları arası CBOT ve NSYE'den alınan günlük fiyat verileri ile getiriler ve varyansları modellenmişti. Rapor yayınlanma günü etkisinin tespiti için WASDE raporlarının 120 rapor yayınlanma günü ve COT raporlarının 522 rapor yayınlanma 
günü kukla değişken olarak modellere eklenmiştir. WASDE için rapor yayınlandığı tarihin beş gün öncesi ve beş gün sonrası etkilere bakılmıştır. COT raporu için haftanın her günü varyans üzerine etkilere bakılmıştır.

Buğday için WASDE rapor gününde oynaklığın artma etkisi görülse bile istatistiki olarak anlamlı sonuç çıkmamıştır. Ancak raporun 3 . gününden sonra oynaklığı düşürücü etkisinin anlamlı olduğu görülmektedir. Bu ise piyasa katılımcılarının raporu algılaması ve rapor sonrası buğday vadeli piyasasının daha doğru fiyatlanması ile olabilmektedir. Pamuk vadeli işlem piyasası için WASDE rapor yayınlanma gününde oynaklığın yukarı yönlü olduğu ve anlamlı olduğu görülmüş, rapor yayınlandıktan sonraki gün bilginin piyasalarda tesirini göstermesiyle oynaklığın düştüğü görülmüştür. COT raporunun oynaklığa etkisi üzerine ise, buğdayın oynaklığının pazartesi günü anlamlı bir etkisi olmadığı fakat Salı günü oynaklığın düşürücü etkisi olduğu anlaşılmıştır. Bunun sebebi, piyasanın hafta sonu ve rapor bilgilerini ancak salı günü doğru fiyatlaması sebebiyle olabileceğidir. Pamuğun oynaklığında ise kukla değişken etkisi hafta içi günlerden en yüksek pazartesi günü olduğu görülmüş ve sonuçlar istatistiki olarak anlamlı çıkmıştır. Raporların piyasa oynaklığını etkilediği ve getiri üzerinde etkisi olduğu anlaşılmaktadır. Bu çalışmanın bulgularına göre varyansta pazartesi günü görülen pozitif etkinin COT raporları sebebiyle de olabileceği gibi, bu pozitif etki hafta sonu biriken bilginin pazartesi günü fiyatlara yansıması(Ying, Chen, \& Dorfmann, 2019) sebebiyle de varyansı arttırıcı etken olabileceği intimali arasındadır. COT raporu özelindeki bu ihtimallerin tamamen ayrıştırılması bu çalışmanın bir kısıtıdır, ayrı bir çalışma konusudur.

Pamuk emtiasının oynaklığının rapor günlerinde arttığı görülmüş fakat buğdayda anlamlı bir sonuç görülmemiştir. Buğdayda rapor günlerinden sonra piyasanın oynaklığının düştüğü fakat pamuk emtiasında bu etkinin sınırlı olduğu görülmüştür. Bunun bir sebebi buğday emtiasının işlem hacminin pamuk emtiasına göre çok daha fazla ve piyasasının derin olmasından kaynaklı olabileceğidir. Pamuk emtiası ise spekülasyonlara daha açık bir emtia görünümü sergilemektedir. Bu ayrı bir çalışmaya fikir olacaktır. Yapılan araştırmalar sonucunda hem USDA WASDE raporu hem de CFTC COT raporunun yayınlandığı günlerin getiri oynaklığına etkileri sınırlı olsa da görülmüştür. Bu raporların vadeli işlem piyasalarında getiri üzerindeki etkileri ve fiyat keşfi çalışmalarında analizlere dahil edilmesi faydalı olacaktır.

\section{KAYNAKÇA}

Atakan, T. (2008). İstanbul Menkul Kıymetler Borsası'nda haftanın günü etkisi ve Ocak ayı anomalilerinin ARCH-GARCH modelleri ile test edilmesi. Istanbul Üniversitesi Işletme Fakültesi Dergisi, 98-110.

Bollerslev, T. (1986). Generalized Autoregressive Conditional Heteroscedasticity. Jounal of Econometrics, 31, $307-327$.

Bunek, G. D., \& Janzen, J. P. (2015). Characterizing the Effect of USDA Report Announcements in the Winter Wheat Futures Market Using Realized Volatility. Proceedings of the NCCC-134 Conference on Applied Commodity Price Analysis, Forecasting, and Market Risk Management. St. Louis.

Butler, C. (1999). Matering Value at Risk. GB: Financial Times Prentice Hall.

CFTC. (2018). Agency Financial Report.

CME. (2019, 10 12). Agricultural Products. www.cmegroup.com: https://www.cmegroup.com/trading/agricultural/ adresinden alınmıştır

CME Group. (2019, 10 11). Chicago SRW Wheat Futures Contract Specs. www.cmegroup.com:

https://www.cmegroup.com/trading/agricultural/grain-and-

oilseed/wheat_contract_specifications.html?optionProductld=\&optionExpiration= adresinden alınmıştır

Gökbulut, R. İ., \& Pekkaya, M. (2014). Estimating and Forecasting Volatility of Financial Markets Using Asymmetric GARCH Models: An Application on Turkish Financial Markets. International Journal of Economics and Finance; Vol. 6, No. 4;.

Ho, S. W., \& Lauwer, A. (2018). Is There Smart Money? How Information in the Commodity Futures Market Is Priced into the Cross-Section of Stock Returns with Delay. Paris December 2018 Finance Meeting EUROFIDAI - AFFI. Paris.

Hull, J. (2012). Options, Futures and Other Derivatives. Peardon.

ICE. (2019). Cotton No.2 Futures. Mart 5, 2019 tarihinde https://www.theice.com/products/254/Cotton-No-2-Futures adresinden alındı

Isengildina-Massa, O., Irwin, S. H., Good, D. L., \& Gomez, J. K. (2008). The Impact of Situation and Outlook Information in Corn and Soybean Futures Markets: Evidence from WASDE Reports. Journal of Agricultural and Applied Economics, 89-103.

Karali, B. (2012). Do USDA Announcements Affect Comovements Across Commodity Futures Returns? Journal of Agricultural and Resource Economics, 37(1):77-97.

Kolodziej, M. K. (2013). Crude Oil Prices: Speculation Versus Fundementals.

NASS. (2019). Understanding USDA Crop Forecast. Washington, D.C.: USDA National Agricultural Statistics Service.

Özden, Ü. H. (2008). IMKB Bileşik 100 Endeksi Getiri Volatilitesinin Analizi. İstanbul Ticaret Üniversitesi Sosyal Bilimler Dergisi, 339-350.

Sevütekin, M., \& Nargeleçekenler, M. (2010). Ekonometrik Zaman Serileri Analizi. Ankara: Nobel.

Sinclair, E. (2008). Volatility Trading. New Jersey: John Wiley \& Sons Inc.

TMO. (2019). Hububat Sektör Raporu. Ankara: Toprak Mahsülleri Ofisi Genel Müdürlüğü.

Ying, J., Chen, Y., \& Dorfmann, H. J. (2019). Flexible Tests For Usda Report Announcement Effects In Futures Markets. American Journal of Agricultural Economics. 